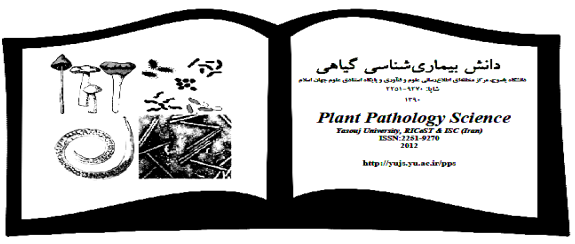

$$
\begin{aligned}
& \text { دانش بيمارىشناسى گياهى }
\end{aligned}
$$

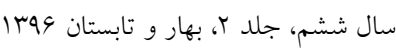

Plant Pathology Science

Vol. 6(2), 2017

\title{
Application of Nanomaterials in Management of Fungal Plant Diseases
}

\section{ABOLGHASEM HOSEINZADEH ${ }^{1}$, MAHDI DAVARI ${ }^{2}$ and AZIZ HABIBI-YANGJEH ${ }^{1}$}

1 and 2-Departments of Chemistry and Plant Protection,University of Mohaghegh Ardabili, Ardabil, Iran ( $\square$ Corresponding author: mdavari@uma.ac.ir)

Received: 13.05.2016

Accepted: 22.04.2017

Hoseinzadeh A., Davari M. and Habibi-Yangjeh A. 2017. Applications of nanomaterials in the fungal plant diseases management. Plant Pathology Science 6(2):68-77.

Abstract: The use of nanotechnology in plant disease management has been seriously considered by researchers in recent years. Some of these reteaches have shown the antifungal effects of nano zinc oxide on Botrytis cinerea and Penicillium expansum; nano copper oxide on Aspergillus flavus; silver nanocomposite compounds $\left(\mathrm{SiO}_{2} / \mathrm{Ag}_{2} \mathrm{~S}\right)$ on Aspergillus niger; $\mathrm{Fe}_{3} \mathrm{O}_{4} / \mathrm{ZnO} / \mathrm{AgBr}$ on Fusarium graminearum, $F$. oxysporum and Botrytis cinerea, and carbon nanomaterials on $F$. graminearum. Their antifungal mechanisms are including: degradation of lipid and protein, damage to cell membranes, water channels blocking by nanomaterials and loss of spore water and plasmolysis and the inhibition of growth or destruction of fungal hyphae and prevent the sporulation.

Key words: Zinc oxide, Nano, Fusarium, Penicillium

$$
\begin{aligned}
& \text { كاربرد نانو مواد در مديريت بيمارىهاى قارجى گياهان } \\
& \text { ابوالقاسم حسينزاده '، مهدى داورى 'rه هز عزيز حبيبى ينغجه ' }
\end{aligned}
$$

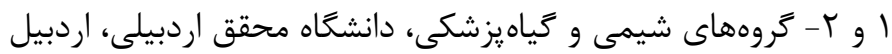

$$
\begin{aligned}
& \text { دريافت: }
\end{aligned}
$$

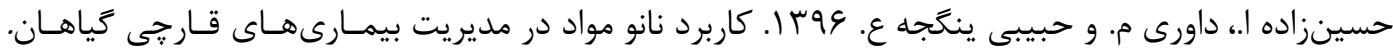

$$
\begin{aligned}
& \text { دانش بيمارىشناسى كياهى }
\end{aligned}
$$

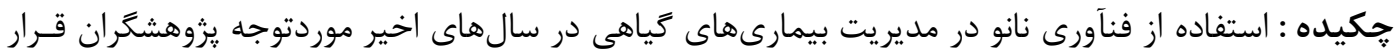

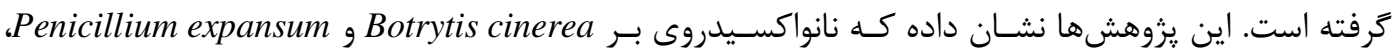

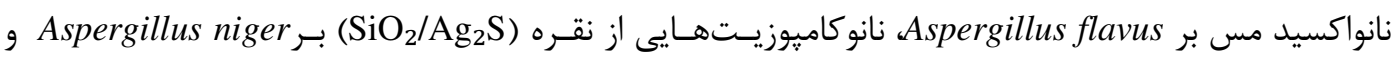

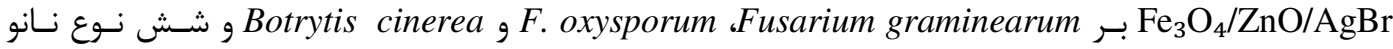

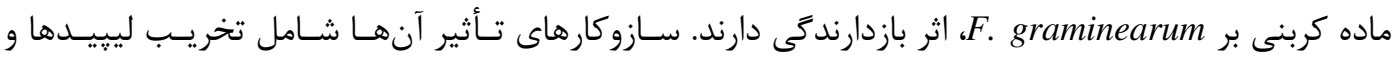

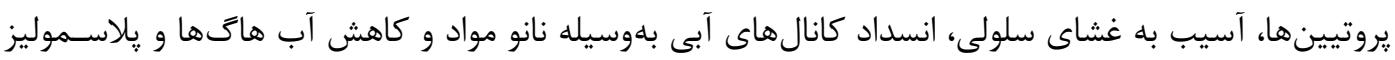

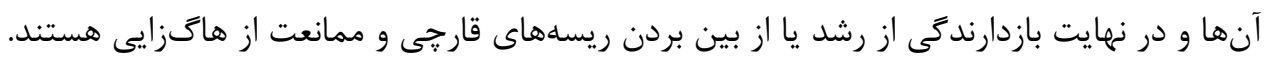

$$
\begin{aligned}
& \text { وازههاى كليدى: اكسيدروى، نانو، Penicillium ،Fusarium }
\end{aligned}
$$




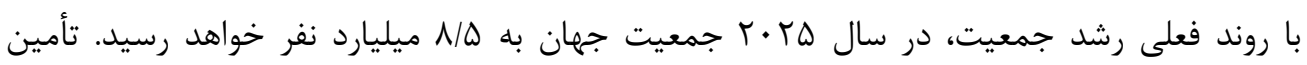
امنيت غذايى براى اين جمعيت عظيم، نياز به توسعهى همهجانبه در بخش كشاورزى دارد. در اين راستا، استفاده از ارقام زراعى :برمحصول مىتواند تا حدى راهگشا باشد، اما عوامل محدودكننده و خسارتزا را نبايد

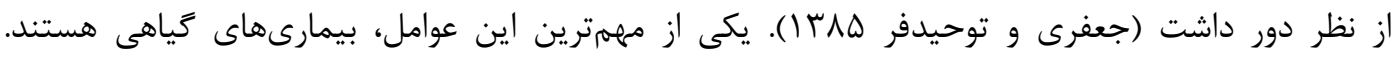
هرساله بخش قابلتوجهى از توليدات گياهى در اثر بيمارىهاى گياهى از بين مىروند و اين در حالى است كه بيش از · • ميليون نفر در جهان از فقر غذايى رنج مىبرند (Strange and Scott 2006). قارجهاى بيمارىزا بلتنهايى موجب كاهش ·r درصدى محصولات غذايى عمده در دنيا مىشوند. تاكنون، روشهاى متعددى براى كنترل بيمارىهاى كياهى به كار كرفته شده است كه از آن جمله مىتوان به مبارزه با ناقلين بيمارى، ريشه كنى درختان و كَاهان آلوده يا هرس اندامها و شاخ و برى آلودهى درختان، استفاده از ارقام مقاوم، روشهاى بيولوزيكى و استفاده از سموم شيميايى اشاره كرد (Agrios 2005). مىتوان كفت كه كنترل شيميايى رايجترين شيوهى كنترل آفات، بيمارىهاى كياهى و علفهاى هرز است و علىرغم زيانها و خطرات استفاده از سموم شيميايى، اين شيوه همجنان بلعنوان قاطعترين روش در سراسر جهان حتى در ييشرفتهترين كشورها مورداستفاده قرار مى گيرد (Rezaei-Moghaddam et al. 2006). در طول سالهاى • 19 تا • 191 قارجكشهاى بنزيميدازولى، كارباماتها و بازدارندههاى دىمتيلاسيون اركوسترول بهتنهايى و يا تركيبى مىتوانستند بيمارى كياهان را بهخوبى مهار كنند تا اينكه اولين ززارش مقاومت معنىدار جدايههاى بيماركر در مقابل يك قارجكش بنزيميدازولى در جمعيتهاى مزرعهاى در انگلستان گَزارش گرديد (Kendall et al. 1994) يس از آن نيز گزارشهايى از عدم كارايى قارجششهاى ديخرى همجون كاربندازيم، فلوزيلازول و ايوكسى كونازول عليه عوامل بيمارىزا ارائه شد (Oxley et al. 2003). بنابراين استفادهى مكرر و بعرويه از تركيبات شيميايى، علاوه بر آلودىى محيطزيست، موجب بروز يديدهى مقاومت عوامل بيمارىزا در برابر آفتكشها شده و در نتيجه، يتانسيل خسارتآفرينى اين عوامل را بهشدت افزايش مىدهد (Narayanasamy 2002). تركيبات شيميايى كه بdصورت مصنوعى توليد مىشوند، علاوه بر آلودگىهاى زيستمحيطى، سلامت بشر را نيز تهديد مىكنند (Afzal et al 1997). بنابراين نياز به يزوهش در راستاى 
كشف مواد ضد قارجى نوين كه سازگًار با محيطزيست و بهآسانى قابل تهيه باشد، ضرورى است ( Agrios 2005). يكى از روشهاى مؤثر، استفاده از فنآورى نانواست كه مىتواند با تبديل مواد به نانو ذرات، موجب افزايش خاصيت ضد ميكروبى آنها شود (صدروى و خردمند مطلق بوبr). افزايش فعاليت ضد قارجى نانو ذرات در مقايسه با نمكهاى آنها، به خواص منحصر به فرد نانو ذرات از جمله مساحت سطح مؤثر بيشتر مربوط مىشود (Kanhed et al. 2014). مطالعات اخير، فعاليتهاى ضد ميكروبى براى نانو ذرات مختلف از جمله نقره، مس و اكسيد روى را ثابت كرده است. (He et al. 2011) در اين مقاله به بررسى عملكرد ضدقارجى حند نانو ماده كه تاكنون موردمطالعه قرار كرفته و نكات اثر آنها يرداخته مىشود.

\section{1 - فعاليت ضد قارجى نانو ذرات اكسيد روى}

در مقايسه با مواد آلى، مواد معدنى ماند اكسيد روى، داراى يايدارى بالا، انتخابيذيرى و مقاومت بالا در برابر حرارت هستند. بهعلاوه، روى يك مادهى معدنى سازكار با سلامت بشر است و نانو ذرات اكسيد روى سازگًارى مناسبى با سلولهاى انسانى دارند (Padmavathy and Vijayaraghavan 2008). تاكنون خاصيت ضد قارجى و ضد ميكروبى يودر اكسيد روى بلصورت توده (Bulk)، اثبات و نشان داده شده است كه اكسيد روى در ابعاد كوجك، خاصيت ضد قارجى قابلتوجهى دارد (Sawai and Yoshikawa 2004). به همين دليل، تركيبات روى در كشاورزى اغلب بهعنوان قارجكش مورداستفاده قرار مى گيرند (Waxman 1998).

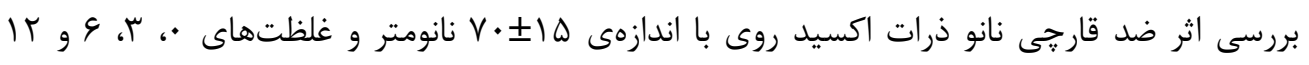
Penicillium expansum عامل كيك خاكسترى و Botrytis cinerea Pers. ميلى و برل بر ليتر بر دو قارج و (Scanning Electron Microscopy, SEM) عامل كيك سبز با ميكروسكوب الكترونى روبشى Link. طيفبينى رامان (Raman spectra)، نشان داد كه نانو ذرات اكسيد روى، فعاليت ضد قارجى متفاوتى بر اين دو قارج دارند. بدين ترتيب كه در قارج Botrytis cinerea از طريق تغيير شكل ريسهها و تأثير بر عملكرد سلولى و در قارج Penicillium expansum با تخريب ليييدها و يروتيينها از رشد قارج جلوكيرى مىكنند و در نهايت منجر به از بين رفتن ريسههاى قارج مىشود. نتايج نشان داد كه با افزايش غلظت نانو ذرات اكسيد روى، ميزان بازدارندگى از رشد قارج افزايش مىيابد. بلطورى كه براى غلظتهاى بيشتر از سه ميلىمول بر ليتر ميزان بازدارندىى از رشد قارج بسيار خشمخير است(He et al. 2011). 


\section{r - فعاليت ضد قارجى نانوكاميوزيتى اكسيد مس}

نانو ذرات اكسيد مس (CuO) داراى خاصيت بازدارندگى از رشد ريزجانداران هستند ( Borkow and Gabbay 2004, Gabbay et al. 2006 به همين دليل از نانو ذرات اكسيد مس براى تهيهى ماسك صورت، باند پانسمان و جورابهاى ضد ميكروبى استفاده مىشود (Borkow et al. 2010). اكسيد مس بهعنوان يك عامل ضد قارجى، به دليل ارزان بودن و روش آمادهسازى ساده موردتوجه قرار گرفته است، هر جند كه براى برخى قارجها نمىتواند بازدارنده باشد. به همين دليل كاميوزيت آن با ساير تركيبات، يكى روش مؤثر خواهد بود كه در بين آنها، اكسيد روى به دليل خواص جالبتوجه از جمله انرزى بيوندى برانگَختخى بالا و يايدارى حرارتى، بيشتر مورد توجه قرار گرفته است. جفت شدن اكسيد مس و اكسيد روى موجب بهبود خاصيت ضد قارجى و نيز خواص فيزيكى شيميايى مىشود. هر دو ماده ارزانقيمت و دوستدار محيطزيست مىباشند Aspergillus flavus محققين اثر ضد قارجى نانو كاميوزيت CuO/ZnO در قارج. (Phiwdang et al. 2013) با استفاده از روش اختلاط با محيط كشت موردبررسى قرار دادند و با اندازمكيرى ميزان رشد يركنهى Link. قارج، ميزان بازدارندگى محاسبه گرديد. نتايج نشان داد كه اكسيد مس بهصورت خالص نيز از رشد قارج جلوكيرى مى كند. آنها نشان دادند كه اكسيد مس مىتواند به غشاى سلولى قارجها آسيب وارد كرده و از رشد آنها جلوكيرى نمايد. البته طبق نتايج يزوهش مذكور، زمانى كه اكسيدروى با اكسيدمس جفت مىشود، ميزان بازدارندكى به ميزان جشمخيرى افزايش مىيابد. حضور اكسيدروى باعث انتقال بار بيشتر و بهتر مىشود كه اين امر مىتواند به خاصيت ضد قارجى اكسيدمس كمك كند و انتقال بار در اكسيدمس اتفاق بيفتد (Phiwdang et al. 2013).

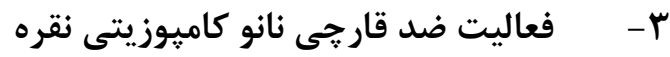

مواد بر پايایى نقره در زمينههاى مختلف از جمله يزشكى بهعنوان عوامل ضد ميكروبى استفاده مىشوند (Grunlan et al. 2005). اخيراً مطالعه در خصوص استفاده از نانو مواد در زمينههاى مختلف توسعه زيادى پِيدا كرده است كه اين يزوهشها شامل برهمكنش نانو ذرات نقره با سيستمهاى زيستى هم مىشود (Dias et al. 2006). هرجند كه تركيبات حاوى يون نقره نسبت به خود ذرات نقره ممكن است براى اين كاربردها بهتر باشند، اما كمتر موردبررسى قرار گرفتهاند. به عبارتى، تركيبات داراى يون نقره در فاز نانو در 
مقايسه با نانو ذرات فلزى مىتوانند مؤثرتر باشند. كزارشهاى مربوط به تأثير ضد ميكروبى نانو مواد نقرهى فلزى، حاكى از آزاد شدن يونهاى Ag در اثر اكسايش در آب است (Kumar et al. 2005). اين اجزاى يونى با مولكولهاى زيستى موجود در عوامل بيمارىزا، از طريق كروههاى الكترون دهندهى موجود در آنها از جمله گوكرد، نيتروزن و اكسيرن برهمكنش شديدى دارند (Fox 1968). محققين بلمنظور ارزيابى خاصيت ا ضد قارجى نانو ذرات نقره، تأثير نانو كاميوزيت A. niger مانع از رشد و هاگزايى $\mathrm{SiO}_{2} / \mathrm{Ag}_{2} \mathrm{~S}$ مورسى قرار دادند. نتايج نشان داد كه نانو كاميوزيت مىشود. همجنين در استفاده از $\mathrm{SiO}_{2}$ خالص نيز مشاهده شد كه $\mathrm{SiO}_{2}$ بلنتهايى تأثيرى بر ميزان رشد قارج ندارد و معلوم شد كه خاصيت ضد قارجى نانو كاميوزيت استفاده از $\mathrm{Ag}_{2} \mathrm{~S}$ بدون حضور $\mathrm{SiO}_{2}$ نشان داد كه ميزان بازدارندكى نانو كاميوزيت $\mathrm{SiO}_{2} / \mathrm{Ag}_{2} \mathrm{~S}$ بيشتر از بهتنهايى است، بنابراين نتيجه كرفتند كه Ag $\mathrm{Ag}_{2} \mathrm{~S}$ Ag افزايشدهندهى سطح تماس نانو كاميوزيت با قارج عمل مى كند. همجنين درصدهاى وزنى متفاوتى از در نانو كاميوزيت ${ }^{2} \mathrm{SiO}_{2} / \mathrm{Ag}_{2} \mathrm{~S}$ بازدارندكى از رشد قارج توسط نانو كاميوزيت افزايش مىيابد (Fateixa et al. 2009). فعاليت ضد قارجى نانو كاميوزيت Fusarium graminearum در مقابل قارجهاى، $\mathrm{Fe}_{3} \mathrm{O}_{4} / \mathrm{ZnO} / \mathrm{AgBr}$ Botrytis cinerea F. oxysporum TEM SEM مادونقرمز (FT-IR)) و تكنيك مغناطيسسنج نمونه مرتعش (VSM) موردمطالعه قرار گرفتند و فعاليت ضد قارجى نانو كاميوزيت با بررسى سينتيك تخريب قارجهاى ذكرشده موردبررسى قرار كرفت. نانو كاميوزيت

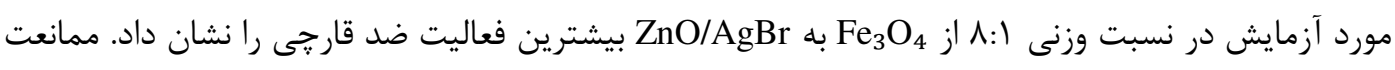
از جوانهزنى و در نهايت تخريب ماكروكنيدىهاى F. graminearum در شكل ا نشان داده شده

است(Hoseinzadeh et al. 2016).

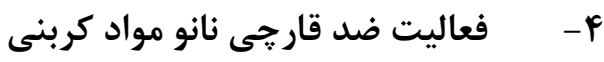

در تحقيقى با بررسى اثر ضدقارجى نانو مواد كربنى در كنترل برخى قارجهاى بيمارىزاى كياهى اعلام 
شد كه اين نانو مواد داراى خاصيت ضدقارجى روى قارجهاى Fusarium graminearum Schwabe و Fock (Peck) Wollenw. مىباشد (Wang et al. 2014). در اين يزوهش، مقادير متفاوتى از شش نوع نانو مواد كربنى (CNMs, carbon nanomaterials) شامل نانو مواد كربنى تكلايه، نانولولههاى كربنى جندلايه (MWCNTs, multi-walled carbon nanotubes)، كرافن اكسيد (GO, graphene oxide)، كرافن اكسيد كاهشيافته (rGO, reduced graphene oxide)، فلورن (C60, fullerene) و كربن فعال ( AC, activated) (carbon به محيط كشت سيبزمينى -دكستروز- آكار (PDA, Potato Dextrose Agar) اضافه شد و سپس قارجها در محيط كشت حاوى نانو مواد كربنى مايهزنى شدند. بعد از قراركيرى در انكوباتور، ميزان بازدارندگى با اندازهگيرى ميزان رشد شعاعى قارجها محاسبه شد. نتايج نشان داد كه تماس مستقيم نانو مواد كربنى با هاگها، نقش مهمى در فعاليت ضدقارجى آنها دارد، بنابراين يوشش هاگها توسط نانو مواد كربنى يكى از عوامل مؤثر در فعاليت ضد قارجى آنها در برابر هاگها محسوب مىشود. با توجه به اينكه انواع مختلف نانو مواد كربنى، فعاليت ضد قارجى متفاوتى از خود نشان دادند، بنابراين بايد عوامل ديكرى نيز در فعاليت ضد قارجى آنها سهيم باشند كه در اين بين، نيروهاى واندروالس مىتواند يكى از عاملهاى مؤثر باشد. جون احتمالاً يك نيروى قوى باعث متراكم شدن و تشكيل هاگ- نانولوله مىشود، بنابراين تماس نانو مواد

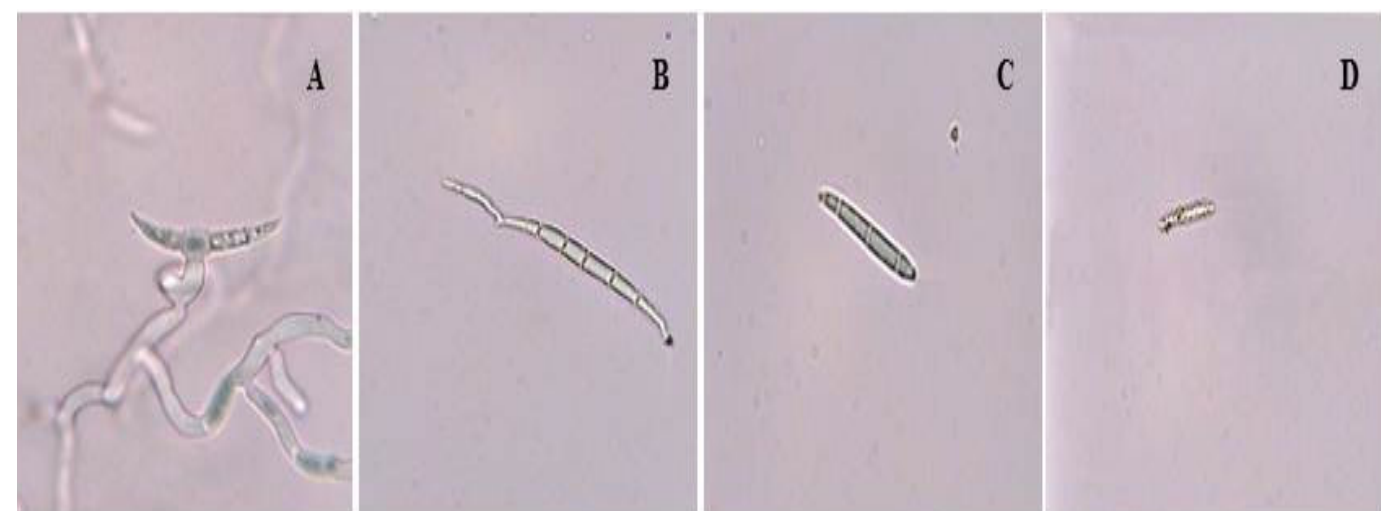

شكل 1- تصاوير ميكروسكويى ماكروكنيدىهاى F. graminearum در معرض نانو كاميوزيت شاهد (A) : Fe $\mathrm{Fe}_{3} / \mathrm{ZnO} / \mathrm{AgBr}$

Figure 1. Optical microscopic images for treatment of Fusarium graminearum by the $\mathrm{Fe}_{3} \mathrm{O}_{4} / \mathrm{ZnO} / \mathrm{AgBr}$ (1:8) nanocomposite: (a) control, (b) after 20 mintreatment, (c) after $60 \mathrm{~min}$ treatment, (d) after 120 min treatment . 
با قارج، عامل كليدى براى فعاليت ضدقارجى نانو مواد كربنى است. هاگهاى تيمار شده با نانو مواد كربنى، بعد از سه ساعت قرارگيرى در مجاورت نانو مواد كربنى، شكل و پيكربندى معمول خود را از دست مىدهند و سيتويلاسم آنها جمع مىشود. اين نتايج مىتواند نشانگر پِلاسموليز باشد كه در نتيجهى از دست دادن آب هاتها در مجاورت نانو مواد كربنى رخ مىدهد. با توجه به اينكه آب يك عامل اساسى براى تندش هات و ازسركيرى متابوليسم سلولى و رشد است، بنابراين هر عاملى كه آبخيرى هاتها را مختل كند، مانع از جوانهزنى و رشد هاگها مىشود. مكانيسم جلوگيرى از آبخيرى هاگها در حضور نانو مواد كربنى فعلاً روشن نيست، اما ممكن است نانو مواد كربنى بلوسيلهى جذب سطحى درغلظتهاى بالا با انسداد كانالهاى آبى موجود در هاگها، مانع از رشد و گسترش هاگها شوند. بنابراين انسداد كانالهاى آبى بلوسيلهى نانو مواد كربنى، موجب كاهش آب هاگها و در نهايت، يلاسموليز مىشود. براى اثبات اين فرضيه، ميزان آب هاگهاى شاهد و هاگهاى تيمار شده با نانو مواد كربنى، بلهوسيله آناليز حرارتى ( TGA,Thermal gravimetric (analysis معرض نانو مواد كربنى تك لايه \% 1 است كه اين نتايج، كاهش آب هاگها بعد از قراركيرى در معرض نانو

مواد كربنى را تأييد مى كند (Wang et al. 2014).

\section{نتيجهَ}

با توجه به مضرات سموم شيميايى براى مقابله با عوامل بيمارىزا، لزوم ارائهى راهكارى نوين براى رسيدن به كشاورزى اركانيك و پايدار بسيار ضرورى به نظر مىرسد كه در اين راستا با توسعهى روزافزون نانو فناورى، ورود آن در كشاورزى و بلويزه مقابله با عوامل بيمارىزاى گياهى، بسيار مؤثر بوده و استفاده از نانو مواد داراى خاصيت ضد قارجى مىتواند گام خوبى در مديريت بيمارىهاى گَياهى در كلخانه، مزرعه، باغ و بلوويزه بيمارىهاى يس از برداشت محسوب شود. معرفى برخى از نانو مواد مههم، شناخت سازوكارهاى اثر ضدقارجى اين نانو مواد و بررسى روشهاى فرموله نمودن بهمنظور انتخاب دقيق آنها براى هركدام از بيماركرها و بهينهسازى كاربرد آنها ضرورى به نظر مىرسد. از جالشهاى پيش رو در بهكاركيرى اين مواد در كنترل بيمارىهاى كياهى مىتوان بهاحتمال تأثيرات منفى آنها روى قارجها و باكترىهاى مفيد، احتمال ماندًارى برخى از مواد سمى در طبيعت و احتمال تجزيه آنها در مقابل نور يا بارندگى و غيره اشاره كرد. 
بنابراين اجراى يزوهشهاى تكميلى براى انتخاب بهترين تركيبات و لحاظ جنبههاى زيستمحيطى، اقتصادى

$$
\text { و جوانب ديكر اين فناورى با همكارى بيمارىشناسان كياهى و متخصصين فنآورى نانو ييشنهاد مىشود. }
$$

References

ا. صدروى، م. و خردمند مطلق، ق. זوبا. كاربرد فنآورىهاى نانو در بيمارىشناسى گياهى. دانش

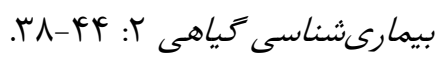

ז. جعفرى، م. و توحيدفر، م. لییّا. كياهان تراريخت: ايمنى، مزيت ها و اثرات بالقوه در كنترل حشرات آفت.

$$
\text { اولين همايش بيوتكنولوزى كشاورزى. كرمانشاه، ايران، لهF-r"Y. }
$$

3. Afzal A. M., Rahber-Bhatti M. H. and Aslam M. 1997. Antibacterial activity of plant diffusate against Xanthomonas campestris pv. citri. International Journal of Pest Management 43:49-53.

4. Agrios G. N. 2005. Plant Pathology, $5^{\text {th }}$ ed. Academic Press, San Francisco, California. 922p.

5. Borkow G. and Gabbay J. 2004. Putting copper into action: copper impregnated products with potent biocidal activities. Federation of American Societies for Experimental Biology Journal 18:1728-1730 ,

6. Borkow G., Zhou S. S., Page T. and Gabbay, J. 2010. A novel antiinfluenza copper oxide containing respiratory face mask. PLoS One 5:e11295.

7. Dias H. V. R., Batdorf K. H., Fianchini M., Diyabalanage H. V. K., Carnahan S., Mulcahy R., Rabiee A., Nelson K., van Waasbergen L. G. and Inorg J. 2006. Antimicrobial properties of highly fluorinated silver (1) tris (pyrazolyl) borates. Biochemistry 100:158-160.

8. Fateixa S., Marcia C. N., Adelaide A., Joao O. and Tito T. 2009. Anti-fungal activity of $\mathrm{SiO}_{2} / \mathrm{Ag}_{2} \mathrm{~S}$ nanocomposites against Aspergillus niger. Colloids and Surfaces B: Biointerfaces 74:304-308.

9. Fox C. L. 1968. Silver sulfadiazine-a new topical therapy for Pseudomonas in burns. Archives of Surgery 96:184-188.

10.Gabbay J., Mishal J., Magen E., Zatcoff R. C., Shemer-Avni Y. and Borkow G. 2006. Copper oxide impregnated textiles with potent biocidal activities. Journal of Industrial Textiles 35:323-335

11.Grunlan J. C., Choi J. K. and Lin A. 2005. Antimicrobial behavior of polyelectrolyte multilayer films containing certimide and silver. Biomacromolecule 6:1149-1153. 
12.He L., Liu Y., Mustapha A. and Lin M. 2011. Antifungal activity of zinc oxide nanoparticles against Botrytis cinerea and Penicillium expansum. Microbiological Research 166:207-215.

13.Hoseinzadeh A., Habibi-Yangjeh A. and Davari M. 2016. Antifungal activity of magnetically separable $\mathrm{Fe} 3 \mathrm{O} / \mathrm{ZnO} / \mathrm{AgBr}$ nanocomposites prepared by microwave-assisted method. Progress in Natural Science: Materials International 26:334-340

14.Kanhed P., Birla S., Gaikwad S., Gade A., Seabra A. B., Rubilar O., Duran N. and Rai M. 2014. In vitro antifungal efficacy of copper nanoparticles against selected crop pathogenic fungi. Materials Letters 115:13-17.

15.Kendall S., Hollomon D. W., Ishi H. and Heaney, S. P. 1994. Characterization of benzimidazole resistant strains of Rhynchosporium secalis. Pesticide Science 40:175-181.

16.Kumar R., Howdle S., Munstedt H. and Biomed J. 2005. Polyamide/silver antimicrobials: effect of filler types on the silver ion release. Journal of Biomedical Materials Research Part B: Applied Biomaterials 75:311-319.

17.Narayanasamy A. 2002. The ACCESS model: a transcultural nursing practice framework. British Journal of Nursing 11:643-650.

18.Oxley S. J. P., Cooke L. R., Black L., Hunter A. and Mercer P. C. 2003. Management of Rhynchosporium in different barley varieties and cropping systems. Home-Grown Cereals Authority, Project Report 315, London.

19.Padmavathy N. and Vijayaraghavan R. 2008. Enhanced bioactivity of ZnO nanoparticles-an antimicrobial study. Science and Technology of Advanced Materials 9:1-7.

20.Phiwdang K., Phensaijai M. and Pecharapa W. 2013. Study of antifungal activities of $\mathrm{CuO} / \mathrm{ZnO}$ nanocomposites synthesized by co-precipitation method. Advanced Materials Research 802:89-93

21.Rezaei M. K., Karami E. and Gibson J. 2006. Conceptualizing sustainable agriculture: Iran as an illustrative case. Journal of Sustainable Agriculture 27:25-56.

22.Sadravi M. and Kheradmand Motlagh G. 2013. Applications of nanotechnology in plant pathology. Plant Pathology Science 2:38-44.

23.Sawai J. and Yoshikawa T. 2004. Quantitative evaluation of antifungal activity of metallic oxide -powders $(\mathrm{MgO}, \mathrm{CaO}$ and $\mathrm{ZnO})$ by an indirect conductimetric assay. Journal of Applied Microbiology 96:803-809.

24.Strange R. N. and Scott P. R. 2005. Plant disease: A threat to global food security. Annual Review of Phytopathology 43:83-116. 
كاربرد نانو مواد در مديريت بيمارىهاى قارجى گياهان Plant Pathology Science (ISSN:2251-9270) Yasouj University,RICeST \& ISC (Iran) Vol. 6(2), 2017

25.Wang X., Liu X., Chen J., Han H. and Yuan Z. 2014. Evaluation and mechanism of antifungal effects of carbon nanomaterials in controlling plant fungal pathogen. Carbon 68:798-806.

26.Waxman M. F. 1998. The Agrochemical and Pesticides Safety Handbook. CRC Press. Florida. .616p. 